Jackson, A., Jonkers, A. R. T. \& Walker, M. Four centuries of geomagnetic secular variation from historical records. Phil. Trans. R. Soc. Lond. A 358(1768), 957-990 (2000)

4. Backus, G. E. \& Gilbert, F. Numerical applications of a formalism for geophysical inverse problems Geophys. J. R. Astron. Soc. 13, 247-276 (1967).

. Parker, R. L. Geophysical Inverse Theory (Princeton Univ. Press, Princeton, 1994)

6. Tikhonov, A. N. \& Arsenin, V. Y. Solutions of Ill-posed Problems (John Wiley and Sons, London, 1977).

Roberts, P. H. \& Glatzmaier, G. A. A test of the frozen-flux approximation using a new geodynamo model. Phil. Trans. R. Soc. Lond. 358, 1109-1121 (2000)

8. Bondi, H. \& Gold, T. On the generation of magnetism by fluid motion. Mon. Not. R. Astron. Soc. 110, 607-611 (1950).

9. Gull, S. F. \& Daniell, G. J. Image reconstruction from incomplete and noisy data. Nature 272, 686-690 (1978).

10. Gull, S. F. \& Skilling, J. Maximum entropy method in image processing. IEEE Proc. 131(F), 646-659 (1984).

11. Buck, B. \& Macaulay, V. A. (eds) Maximum Entropy in Action (Oxford Univ. Press, Oxford, 1991).

12. Christensen, U., Olsen, P. \& Glatzmaier, G. A. Numerical modelling of the geodynamo: a systematic parameter study. Geophys. J. Int. 138, 393-409 (1999).

13. Constable, C. G., Parker, R. L. \& Stark, P. B. Geomagnetic field models incorporating frozen-flux constraints. Geophys. J. Int. 113, 419-433 (1993).

14. Baumgardner, J. \& Fredrickson, P. O. Icosahedral discretization of the two-sphere. SIAM J. Num. Anal. 22, 1107-1115 (1985).

15. Gull, S. F. \& Skilling, J. The MEMSYS5 User's Manual (Maximum Entropy Data Consultants Ltd, Royston, 1990); available at 〈http://www.maxent.co.uk/documents/MemSys5_manual.pdf〉.

16. Hulot, G., Eymin, C., Langlais, B., Mandea, M. \& Olsen, N. Small-scale structure of the geodynamo inferred from Oersted and Magsat data. Nature 416, 620-623 (2002).

17. Gubbins, D. \& Kelly, P. Persistent patterns in the geomagnetic field during the last 2.5 Myr. Nature 365, 829-832 (1993).

18. Zhang, K. On equatorially trapped boundary inertial waves. J. Fluid Mech. 248, $203-217$ (1993).

19. Malkus, W. V. R. Hydromagnetic planetary waves. J. Fluid. Mech. 28, 793-802 (1967).

20. Hide, R. Free hydrodynamic oscillations of the Earth's core and the theory of the geomagnetic secular variation. Phil. Trans. R. Soc. Lond. 259, 615-647 (1966).

21. Holme, R. \& Bloxham, J. The treatment of attitude errors in satellite geomagnetic data. Phys. Earth Planet. Int. 98, 221-233 (1996)

22. Olsen, N. \& members of the Ørsted International Science Team. Ørsted Initial Field Model. Geophys Res. Lett. 27, 3607-3610 (2000).

Acknowledgements The provision of high-quality Oersted data is due to the efforts of the Oersted Project team, for which I am grateful. I thank C. Constable and R. Parker for their hospitality, discussions and sharing of software, and C. Finlay for comments.

Competing interests statement The author declares that he has no competing financial interests.

Correspondence and requests for materials should be addressed to A.J.

(a.jackson@earth.leeds.ac.uk).

\section{In situ experimental evidence of the fate of a phytodetritus pulse at the abyssal sea floor}

\section{U. Witte ${ }^{1}$, F. Wenzhöfer ${ }^{1}$, S. Sommer ${ }^{2}$, A. Boetius ${ }^{1}$, P. Heinz ${ }^{3}$, N. Aberle ${ }^{1 \star}$, M. Sand ${ }^{1}$, A. Cremer $^{2}$, W.-R. Abraham ${ }^{4}$, B. B. Jørgensen ${ }^{1}$ \& 0. Pfannkuche ${ }^{2}$}

${ }^{1}$ Max-Planck-Institute for Marine Microbiology, Celsiusstrasse 1, 28359 Bremen, Germany

${ }^{2}$ GEOMAR Research Center, Wischhofstrasse 1-3, 24148 Kiel, Germany

${ }^{3}$ Institute of Geosciences, University of Tübingen, Sigwartstrasse 10,

72076 Tübingen, Germany

${ }^{4}$ Gesellschaft für Biotechnologische Forschung, Mascheroder Weg 1, 38124

Braunschweig, Germany

* Present addresses: Marine Biological Laboratory, University of Copenhagen, Strandpromenaden 5, DK-3000 Helsingør, Denmark (F.W.); Alfred Wegener Institute for Polar and Marine Research, Columbusstrasse, 27515 Bremerhaven, Germany (A.B.); Max-Planck-Institute for Limnology, Post Box 165, 24302 Plön, Germany (N.A.)

More than $50 \%$ of the Earth's surface is sea floor below 3,000 m of water. Most of this major reservoir in the global carbon cycle and final repository for anthropogenic wastes is characterized by severe food limitation. Phytodetritus is the major food source for abyssal benthic communities, and a large fraction of the annual food load can arrive in pulses within a few days ${ }^{1,2}$. Owing to logistical constraints, the available data concerning the fate of such a pulse are scattered ${ }^{3,4}$ and often contradictory ${ }^{5-10}$, hampering global carbon modelling and anthropogenic impact assessments. We quantified (over a period of 2.5 to 23 days) the response of an abyssal benthic community to a phytodetritus pulse, on the basis of 11 in situ experiments. Here we report that, in contrast to previous hypotheses ${ }^{5-11}$, the sediment community oxygen consumption doubled immediately, and that macrofauna were very important for initial carbon degradation. The retarded response of bacteria and Foraminifera, the restriction of microbial carbon degradation to the sediment surface, and the low total carbon turnover distinguish abyssal from continentalslope 'deep-sea' sediments.

The Porcupine abyssal plain (PAP) is remote from both the continental slope to the east and the Mid-Atlantic Ridge to the west, and thus is largely unaffected by slope processes ${ }^{12}$. The mean annual vertical influx of particulate organic carbon $\left(\mathrm{C}_{\text {org }}\right)$ of approximately $1 \mathrm{~g} \mathrm{C} \mathrm{m}^{-2} \mathrm{yr}^{-1}$ has a strong seasonal pattern, reaching a maximum in mid-summer ${ }^{13}$. Prior to the midsummer maximum, we simulated a settling food pulse by injection of ${ }^{13} \mathrm{C}$-labelled phytodetritus into the chambers of benthic landers and then followed the pathway of tracer $-{ }^{13} \mathrm{C}$ through the abyssal community. Sedimentary $\mathrm{C}_{\text {org }}$ was $0.4 \mathrm{wt} \%$, oxygen penetration depth was $15 \mathrm{~cm}$, and the background sediment community oxygen consumption (SCOC) was $0.44 \pm$ $0.04 \mathrm{mmol} \mathrm{O}_{2} \mathrm{~m}^{-2} \mathrm{~d}^{-1}$.

The change in SCOC due to the enrichment with particulate organic matter (POM) was very rapid: SCOC increased significantly within $2.5 \mathrm{~d}$, and the elevated remineralization rates lasted throughout the experiment (Fig. 1a). Bacteria usually dominate benthic biomass in deep-sea sediments, and are thought to be the primary agents of benthic carbon remineralization ${ }^{14,15}$. At PAP, total microbial biomass accounted for approximately 95\% of benthic biomass, thus most of the increase in SCOC would probably be due to an enhanced microbial respiration. A typical bacterial extracellular enzyme for the degradation of phytodetritus carbohydrates is $\beta$-glucosidase. It generally has a low activity in deep-sea sediments, and is substrate inducible-for example, by the addition of plant detritus ${ }^{16}$. Compared to SCOC, however, the onset of bacterial production of hydrolytic enzymes was retarded: extracellular enzyme activity (EEA) of $\beta$-glucosidase was unchanged after $2.5 \mathrm{~d}$ but had doubled after $8 \mathrm{~d}$ (Fig. 1b), whereas it decreased in the controls. The incorporation of ${ }^{13} \mathrm{C}$ from phytodetritus into bacterial phospholipid-derived fatty acids (PLFA) required even more time: the bacterial biomarkers contained only a moderate amount of excess ${ }^{13} \mathrm{C}$ after $8 \mathrm{~d}$, but the specific uptake of tracer increased significantly within the second and third weeks of the experiment (Fig. 1c). Bacteria had assimilated approximately $1 \mathrm{mg}$ of ${ }^{13} \mathrm{C}$ labelled diatom carbon after $8 \mathrm{~d}$; after $23 \mathrm{~d}$, bacterial assimilation had increased to $4 \mathrm{mg}{ }^{13} \mathrm{C}_{\text {org }}$ (Fig. 2). Total bacterial cell numbers $(0-5 \mathrm{~cm})$ did not increase significantly, but it is possible that net growth of the microbial community was low owing to grazing by larger organisms.

Other than bacteria, Foraminifera and multicellular organisms can ingest fresh phytodetritus directly. Although the ${ }^{13} \mathrm{C}$ pulse chase experiments cannot distinguish between uptake and assimilation for these organisms, the foraminiferal response was retarded and the response pattern very similar to the pattern of extracellular enzyme activity and assimilation of ${ }^{13} \mathrm{C}$ by bacteria: after $2.5 \mathrm{~d}$, labelling of Foraminifera was high, but total uptake of ${ }^{13} \mathrm{C}$ was still low. The specific uptake increased between $8 \mathrm{~d}$ and $23 \mathrm{~d}$, and dominated the carbon uptake by the benthic biota after $23 \mathrm{~d}$ (Figs 1d and 2) despite the low total foraminiferal biomass. A significant increase in Foraminifera biomass was observed after $23 \mathrm{~d}$. In contrast, metazoa became labelled immediately with ${ }^{13} \mathrm{C}$ (Figs 1e, f and 2). Macrofauna, in particular, gained immediate access to the phytodetritus: after $2.5 \mathrm{~d}$, isotope signatures revealed that $77 \%$ of the organisms 

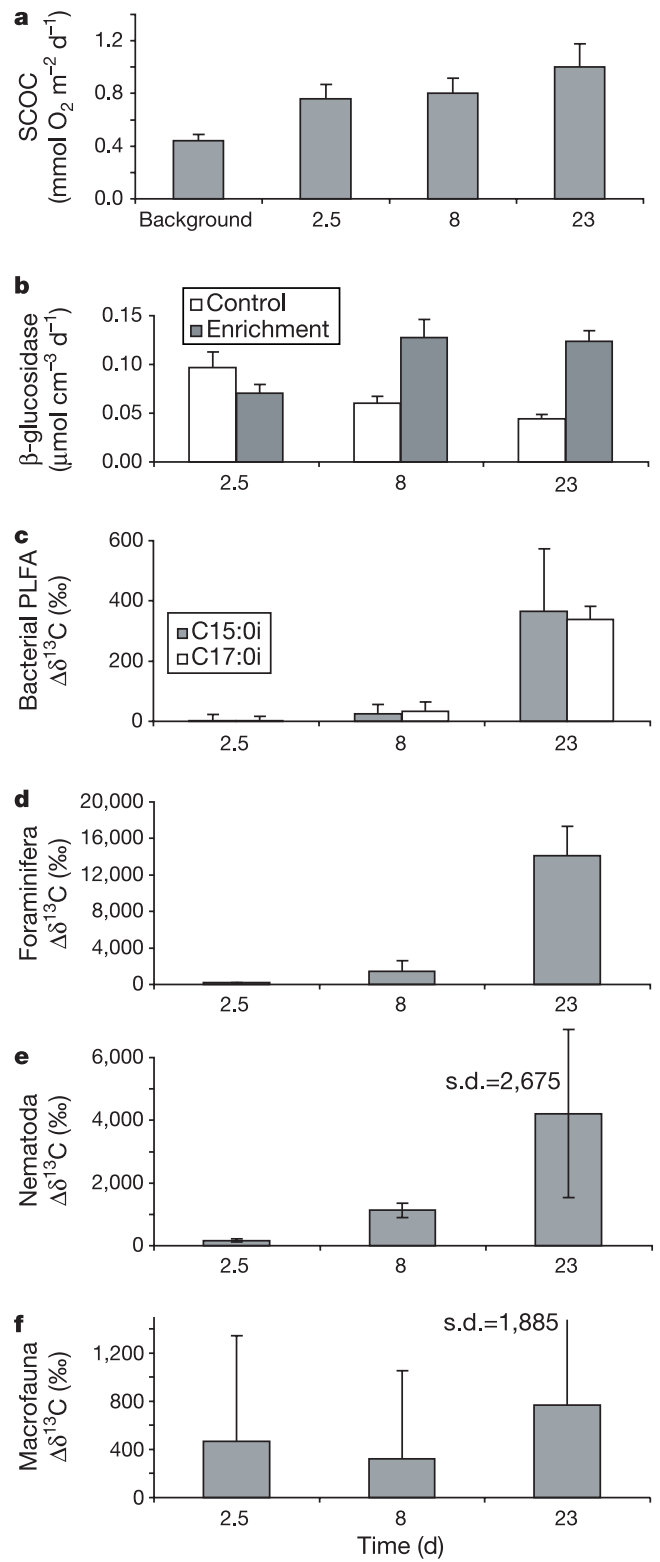

Figure 1 Response of different benthic compartments to POM enrichment. a, SCOC; b, extracellular enzyme activity of $\beta$-glucosidase; $\mathbf{c}$, specific labelling patterns of bacterial $\operatorname{PLFA}\left(\Delta \delta^{13} \mathrm{C}\right), \mathbf{d}-\mathbf{f}$, mean specific uptake $\left(\Delta \delta^{13} \mathrm{C}\right)$ of Foraminifera $(\mathbf{d}, 0-1 \mathrm{~cm})$, Nematoda $(\mathbf{e}, 0-5 \mathrm{~cm})$ and macrofauna $(\mathbf{f}, 0-10 \mathrm{~cm})$. Error bars represent standard deviations. High standard deviations for macrofauna and meiofauna are due to the strong individual differences in labelling between specimens (macrofauna labelling, for example, ranged from $\Delta \delta^{13} \mathrm{C}=-20 \%$ to $\Delta \delta^{13} \mathrm{C}=+5,747 \%$ o $)^{22}$.

had ingested ${ }^{13} \mathrm{C}$-labelled organic material. For total macrofauna, labelling was high throughout the experiments, but varied considerably between the different taxa ${ }^{17}$. The apparent decline of macrofaunal tracer uptake, from $3.4 \mathrm{mg}$ after $8 \mathrm{~d}$ to $1 \mathrm{mg}$ after $23 \mathrm{~d}$, is probably the result of spatial variability in macrofaunal abundance ${ }^{17}$. Macrofauna in the 5-10-cm layer became labelled within days, and meiofauna (Nematoda) at $2-5 \mathrm{~cm}$ depth within weeks (Fig. 3a, b). In contrast, bacterial assimilation of organic carbon mixed below the surface layer was almost negligible: EEA of $\beta$-glucosidase at $2-5 \mathrm{~cm}$ had increased after 3 weeks (Fig. $3 \mathrm{c}$ ), but only minute amounts of tracer were incorporated into subsurface bacterial biomass (Fig. 3d).

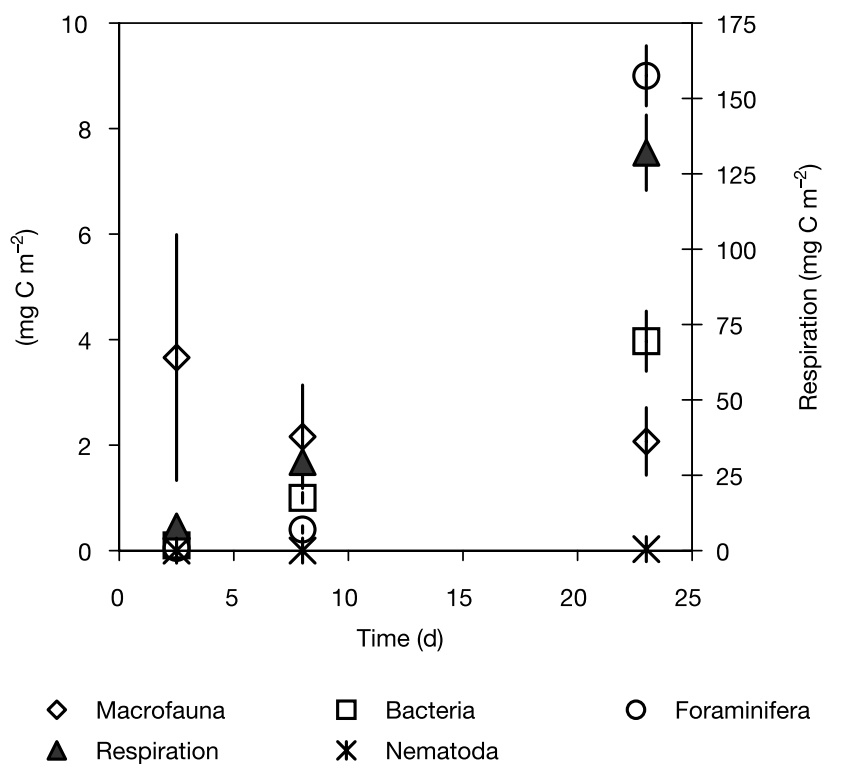

Figure 2 Pathways of ${ }^{13} \mathrm{C}$ labelled phytodetritus through the benthic community with time. (For comparison: total microbial biomass is approximately $2.5 \mathrm{~g} \mathrm{C} \mathrm{m}^{-2}$; macrofauna biomass, $120 \mathrm{mg} \mathrm{C} \mathrm{m}^{-2}$; Foraminifera, $15 \mathrm{mg} \mathrm{C} \mathrm{m}^{-2}$; meiofauna (Nematoda), $5 \mathrm{mg} \mathrm{C} \mathrm{m}^{-2}$ ).

In contrast to our experimental results, studies from the northeast Atlantic Ocean and the North Pacific Ocean reported a time lag of several weeks between the settling of a phytodetritus pulse and an increase in $\operatorname{SCOC}^{7,18,19}$. This discrepancy may relate to the difficulty of following the response to a natural sedimentation event, as well as to the paucity of natural food prior to our experiments and the use of a 'fresh' monoculture different from the normal detrital food material. Despite their low significance in terms of biomass $(<5 \%)$, macrofauna initially dominated the benthic material processing. This implies that a large fraction of the material is passed through the gut system of a larger animal, where its composition is altered, before it becomes available for other (micro)organisms. Multicellular organisms initially outcompete bacteria owing to their higher capacity for directed movement, their ability to structure the sediment, and the advantage of internal digestion. These results are corroborated by the fact that the superabundance of megafauna at PAP could even prevent the accumulation of phytodetritus on the sea floor ${ }^{20,21}$. However, bacteria still sustain a much greater biomass in abyssal sediments than metazoa because of their ability to degrade aged organic material as well as their capacity to survive starvation. At continental-slope depth, macrofauna rapidly subduct labile food down to $5-15 \mathrm{~cm}$ depth where it is degraded quickly by bacteria and deep-dwelling deposit feeders ${ }^{6,22,23}$. In contrast, at abyssal depths, the absence of a deep-dwelling macrofaunal community and lower benthic biomass result in low total carbon processing rates that decrease with increasing depths from the continental shelf $\left(61 \mathrm{mg} \mathrm{C} \mathrm{m}^{-2}\right.$ within $1.5 \mathrm{~d}$; ref. 11) to slope (9$25 \mathrm{mg} \mathrm{C} \mathrm{m}^{-2}$ within $1.5 \mathrm{~d}$; refs 11,23$)$ to abyssal-plain sediments $\left(6 \mathrm{mg} \mathrm{C} \mathrm{m}^{-2}\right.$ within $\left.1.5 \mathrm{~d}\right)$. In our study, $14 \%$ of the $1 \mathrm{~g} \mathrm{C} \mathrm{m}^{-2}$ added were processed within $23 \mathrm{~d}$. This suggests that a large phytodetritus pulse could sustain the elevated levels of activity for long periods (at least several months). This is long enough for many deep-sea organisms to complete their reproductive cycles, which might be synchronized with or triggered by sedimentation events $^{4,24}$.

The present experiments have successfully documented and quantified the first steps of early diagenesis in abyssal sediments. 


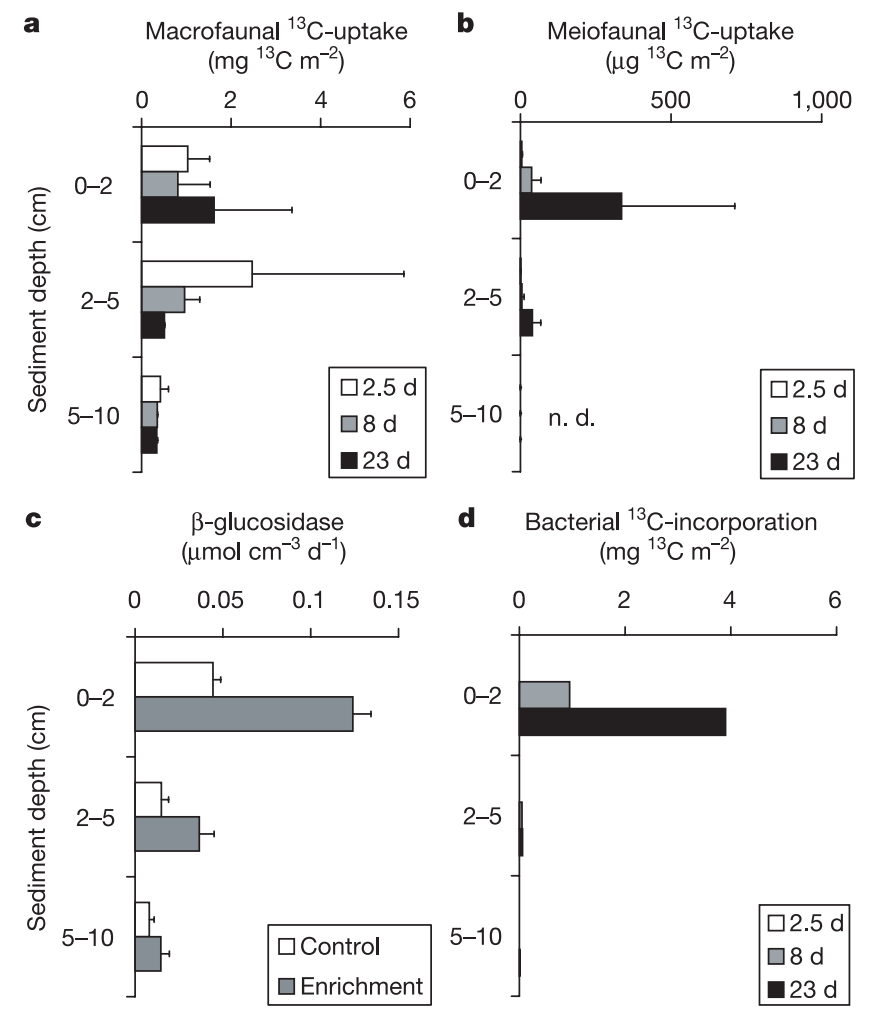

Figure $\mathbf{3}$ Vertical distribution of several quantities within the sediment. $\mathbf{a},{ }^{13} \mathrm{C}$ uptake by macrofauna; $\mathbf{b},{ }^{13} \mathrm{C}$ uptake by meiofauna (Nematoda); $\mathbf{c}$, EEA of $\beta$-glucosidase; $\mathbf{d},{ }^{13} \mathrm{C}$ incorporation by bacteria. Error bars represent standard deviations.

It was demonstrated that there is no significant time lag between the arrival of a food pulse and the increase in SCOC. The macrofaunal community structure appears to be of greater importance for the initial stages of POM degradation. The bacterial and foraminiferal response was retarded, and microbial degradation of POM was restricted to the upper sediment horizon. The retarded response of microbiota, low rates of vertical mixing and the low carbon processing capacity underline the functional differences between continental-slope and deep-sea benthic communities.

\section{Methods}

\section{Experimental design}

$\mathrm{O}_{2}$ penetration depth was determined in situ with a profiling lander equipped with four $\mathrm{O}_{2}$ microelectrodes and two deep-penetrating optical $\mathrm{O}_{2}$ microsensors (optodes) ${ }^{25}$.

Enrichment experiments were carried out with three identical benthic chamber landers, each equipped with three chambers $(0.2 \times 0.2 \mathrm{~m})^{26}$. Each chamber of one lander carried two $\mathrm{O}_{2}$ optodes that continuously recorded the $\mathrm{O}_{2}$ concentration in the chamber water. To simulate a sedimentation event, a suspension of $0.2 \mathrm{~g}$ freeze-dried ${ }^{13} \mathrm{C}$-labelled Thalassiosira rotula ( $98 \pm 1 \%{ }^{13} \mathrm{C} ; \mathrm{C}: \mathrm{N}=13$ ), equivalent to $1 \mathrm{~g} \mathrm{C}_{\mathrm{org}} \mathrm{m}^{-2}$, was injected into each chamber. During the long-term incubations, a pump system exchanged part of the chamber water each week. From each chamber, seven water samples $(50 \mathrm{ml})$ were taken during the incubation, one before and after each pumping cycle. SCOC was determined by Winkler titration of syringe water samples and by optode readings, which agreed very well. Altogether, five short (2.5 d), three medium ( $8 \mathrm{~d}$ ) and three long ( $23 \mathrm{~d}$ ) deployments were carried out during RV Poseidon cruise 260 in May/ June 2000 at $48^{\circ} 50^{\prime} \mathrm{N} ; 16^{\circ} 35^{\prime} \mathrm{W}$ $(4,800 \mathrm{~m}$ water depth) in the PAP. In each lander, one chamber served as control without POM enrichment. Additional sediment cores were taken for the determination of background ${ }^{13} \mathrm{C}$ signatures of the organisms.

\section{Sample processing}

From each incubation, two subcores $(10 \times 20 \mathrm{~cm}$ each) were sliced in layers of $0-1,1-2$, $2-5$ and $5-10 \mathrm{~cm}$ and sieved over 250 and $63 \mu \mathrm{m}$ for macrofauna and meiofauna (Nematoda). After taxonomic identification, all specimen were freeze-dried in vacuo for the subsequent determination of ${ }^{12} \mathrm{C} /{ }^{13} \mathrm{C}$ ratios with an ANCA 20-20 (Europe Scientific) isotope ratio mass spectrometer (IRMS) $)^{25}$. For Foraminifera, $15-40 \mathrm{~cm}^{3}$ of surficial sediment $(0-1 \mathrm{~cm})$ was sieved over $30 \mu \mathrm{m}$ and stored frozen. Plasma-containing
Foraminifera were hand-picked and identified, then decalcified and dried prior to determination of ${ }^{12} \mathrm{C} /{ }^{13} \mathrm{C}$ ratios.

The remaining sediment was sliced in $0-2,2-5,5-10 \mathrm{~cm}$, homogenized and sampled for bacterial biomass (cell counts), EEA of $\beta$-glucosidase and extraction of phospholipids ${ }^{27-29}$. Concentrations of fatty acid methyl esters were determined by gas chromatography-flame ionization detection. Carbon isotope ratios as determined by GC-IRMS (Finnigan MAT 252 coupled with gas chromatograph combustion for compound identification) were corrected by using a mass balance for the one carbon atom in the methyl group added during derivatization.

The carbon isotope ratios are expressed in the delta notation $\left(\delta^{13} \mathrm{C}\right)$ relative to Vienna PDB: $\delta^{13} \mathrm{C}(\%)=\left[\left({ }^{13} \mathrm{C} /{ }^{12} \mathrm{C}\right)_{\text {sample }} /\left({ }^{13} \mathrm{C} /{ }^{12} \mathrm{C}\right)_{\text {reference }}-1\right] \times 1,000$. The uptake or incorporation of ${ }^{13} \mathrm{C}$ label by the organisms is expressed as specific uptake or excess ${ }^{13} \mathrm{C}$ above background (that is, $\Delta \delta^{13} \mathrm{C}=\delta^{13} \mathrm{C}_{\text {sample }}-\delta^{13} \mathrm{C}_{\text {background }}$ ) or total uptake (I) (refs 23,29 ). For bacteria, $I$ was calculated from label incorporation into six bacterial PLFA

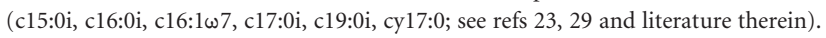

Received 24 January; accepted 2 June 2003; doi:10.1038/nature01799.

1. Billett, D. S. M., Lampitt, R. S., Rice, A. L. \& Mantoura, R. F. C. Seasonal sedimentation of phytoplankton to the deep-sea benthos. Nature 302, 520-522 (1983).

2. Lampitt, R. S. Evidence for the seasonal deposition of detritus to the deep-sea floor and its subsequent resuspension. Deep-Sea Res. I 32, 885-897 (1985).

3. Lochte, K. \& Turley, C. M. Bacteria and cyanobacteria associated with phytodetritus in the deep-sea. Nature 333, 67-69 (1988).

4. Tyler, P. A. Seasonality in the deep sea. Oceanogr. Mar. Biol. Annu. Rev. 26, 227-258 (1988).

5. Smith, K. L. Jr \& Baldwin, R. J. Seasonal fluctuations in deep-sea sediment community oxygen consumption: Central and eastern north Pacific. Nature 307, 624-626 (1984).

6. Graf, G. Benthic-pelagic coupling in a deep-sea benthic community. Nature 341, 437-439 (1989).

7. Drazen, J. C., Baldwin, R. J. \& Smith, K. L. Jr Sediment community response to a temporally varying food supply at an abyssal station in the NE Pacific. Deep-Sea Res. II 45, 893-913 (1998).

8. Sayles, F. L., Martin, W. R. \& Deuser, W. G. Response of benthic oxygen demand to particulate organic carbon supply in the deep sea near Bermuda. Nature 371, 686-689 (1994).

9. Smith, K. L. \& Kaufmann, R. S. Long-term discrepancy between food supply and demand in the eastern North Pacific. Science 284, 1174-1177 (1999).

10. Witbaard, R., Duineveld, G. C. A., Van der Weele, J. A., Berghuis, E. M. \& Reyss, J. P. The benthic response to the seasonal deposition of phytopigments at the Porcupine Abyssal Plain in the North East Atlantic. J. Sea Res. 43, 15-31 (2000).

11. Moodley, L. et al. Bacteria and Foraminifera: Key players in a short-term deep-sea benthic response to phytodetritus. Mar. Ecol. Prog. Ser. 236, 23-29 (2002).

12. Billett, D. S. M. \& Rice, A. L. The BENGAL programme: Introduction and overview. Prog. Oceanogr. 50, 13-25 (2001).

13. Lampitt, R. S. et al. Material supply to the abyssal seafloor in the Northeast Atlantic. Prog. Oceanogr. 50, 27-63 (2001).

14. Rowe, G. T. et al. 'Total' sediment biomass and preliminary estimates of organic carbon residence time in deep-sea benthos. Mar. Ecol. Prog. Ser. 79, 99-114 (1991).

15. Turley, C. Bacteria in the cold deep-sea benthic boundary layer and sediment-water interface of the NE Atlantic. FEMS Microbiol. Ecol. 33, 89-99 (2000).

16. Boetius, A. \& Lochte, K. Effect of organic enrichments on hydrolytic potentials and growth of bacteria in deep-sea sediments. Mar. Ecol. Prog. Ser. 140, 239-250 (1996).

17. Aberle, N. \& Witte, U. Deep-sea macrofauna exposed to a simulated sedimentation event in the abyssal NE Atlantic: In situ pulse-chase experiments using ${ }^{13} \mathrm{C}$-labelled phytodetritus. Mar. Ecol. Prog. Ser. 251, 37-47 (2003).

18. Pfannkuche, O. Benthic response to the sedimentation of particulate organic matter at the BIOTRANS station, $47^{\circ} \mathrm{N}, 20^{\circ} \mathrm{W}$. Deep-Sea Res. 40, 135-149 (1993).

19. Smith, K. L. Jr, Baldwin, R. J., Karl, D. M. \& Boetius, A. Benthic community responses to pulses in pelagic food supply: North Pacific Subtropical Gyre. Deep-Sea Res. 49, 971-990 (2002).

20. Billett, D. S. M. et al. Long-term change in the megabenthos of the Porcupine Abyssal Plain (NE Atlantic). Prog. Oceanogr. 50, 325-348 (2001).

21. Bett, B. J., Malzone, M. G., Narayanaswamy, B. E. \& Wigham, B. D. Temporal variability in phytodetritus and megabenthic activity at the seabed in the deep Northeast Atlantic. Prog. Oceanogr. 50, 349-368 (2001).

22. Levin, L. A. et al. Rapid subduction of organic matter by maldanid polychaetes on the North Carolina slope. J. Mar. Res. 55, 595-611 (1997).

23. Witte, U., Aberle, N., Sand, M. \& Wenzhöfer, F. Rapid response of a deep-sea benthic community to POM enrichment: An in situ experimental study. Mar. Ecol. Prog. Ser. 251, 27-36 (2003).

24. Gooday, A. Biological responses to seasonally varying fluxes of organic matter to the ocean floor: A review. J. Oceanogr. 58, 305-332 (2002).

25. Wenzhöfer, F., Holby, O. \& Kohls, O. Deep penetrating benthic oxygen profiles measured in situ by oxygen optodes. Deep-Sea Res. I 48, 1741-1755 (2001).

26. Witte, U. \& Pfannkuche, O. High rates of benthic carbon remineralisation in the abyssal Arabian Sea. Deep-Sea Res. II 47, 2785-2804 (2000).

27. Boetius, A., Ferdelmann, T. \& Lochte, K. Bacterial activity in sediments of the deep Arabian Sea in relation to vertical flux. Deep-Sea Res. II 47, 2835-2875 (2000).

28. Boschker, H. T. S., de Brouwer, J. F. C. \& Cappenberg, T. E. The contribution of macrophyte derived organic matter to microbial biomass in salt-marsh sediments: Stable isotope analysis of microbial biomarkers. Limnol. Oceanogr. 44, 309-319 (1999).

29. Middelburg, J. J. et al. The fate of intertidal microphytobenthos carbon: An in situ ${ }^{13} \mathrm{C}$-labelling study. Limnol. Oceanogr. 45, 1224-1234 (2000). 
Acknowledgements We thank the officers, crew and shipboard scientific party of RV Poseidon for their support at sea during the expedition POS 260/1-5, and M. Poser, W. Queisser, S. Meyer and V. Meyer for technical assistance with the lander systems. We also thank F. Lipschultz and U. Struck for help with isotope ratio measurements of macrofauna and Foraminifera, and K. Smith for review. This work was funded by the Bundesministerium für Bildung und Forschung as part of the BIGSET programme.

Competing interests statement The authors declare that they have no competing financial interests.

Correspondence and requests for materials should be addressed to U.W. (uwitte@mpi-bremen.de).

\section{Climate change decreases aquatic ecosystem productivity of Lake Tanganyika, Africa}

\author{
Catherine M. O’Reilly ${ }^{1 \star}$, Simone R. Alin ${ }^{1 \star}$, Pierre-Denis Plisnier ${ }^{2}$, \\ Andrew S. Cohen ${ }^{1}$ \& Brent A. McKee ${ }^{3}$
}

${ }^{1}$ Department of Geosciences, University of Arizona, Tucson Arizona 85721, USA ${ }^{2}$ Royal Museum for Central Africa, 3080 Tervuren, and Department of Biology, Namur University, B-5000 Namur, Belgium

${ }^{3}$ Department of Earth and Environmental Sciences, Tulane University, New Orleans, Louisiana 70118, USA

* Present addresses: Environmental Science Program, Vassar College, Poughkeepsie, New York 12603 USA (C.M.O.); Large Lakes Observatory, University of Minnesota, Duluth, Minnesota 55812, USA (S.R.A.)

Although the effects of climate warming on the chemical and physical properties of lakes have been documented ${ }^{1}$, biotic and ecosystem-scale responses to climate change have been only estimated or predicted by manipulations and models ${ }^{1}$. Here we present evidence that climate warming is diminishing productivity in Lake Tanganyika, East Africa. This lake has historically supported a highly productive pelagic fishery that currently provides $25-40 \%$ of the animal protein supply for the populations of the surrounding countries ${ }^{2}$. In parallel with regional warming patterns since the beginning of the twentieth century, a rise in surface-water temperature has increased the stability of the water column. A regional decrease in wind velocity has contributed to reduced mixing, decreasing deep-water nutrient upwelling and entrainment into surface waters. Carbon isotope records in sediment cores suggest that primary productivity may have decreased by about $20 \%$, implying a roughly $30 \%$ decrease in fish yields. Our study provides evidence that the impact of regional effects of global climate change on aquatic ecosystem functions and services can be larger than that of local anthropogenic activity or overfishing.

Lake Tanganyika is a large (mean width, $50 \mathrm{~km}$; mean length $650 \mathrm{~km}$ ), deep (mean depth, $570 \mathrm{~m}$; maximum depth, 1,470 m) north-south trending rift valley lake that is an important source of both nutrition and revenue to the bordering countries of Burundi, Tanzania, Zambia, and the Democratic Republic of Congo. The lake has historically supported one of the world's most productive pelagic fisheries ${ }^{3}$, and the annual harvest in recent years has been estimated to be between 165,000 and 200,000 metric tons $\left(54-66 \mathrm{~kg} \mathrm{ha}^{-1}\right)$, with an equivalent value of tens of millions of US dollars ${ }^{2}$. The lake is oligotrophic and permanently thermally stratified with an anoxic hypolimnion. During the cool windy season (May to September), strong southerly winds tilt the thermocline, causing upwelling of deeper nutrient-rich waters at the south end of the lake and initiating seiche activity ${ }^{4,5}$. Cooling during this season also contributes to a weaker thermocline, and entrainment of deep nutrient-rich waters from the hypolimnion occurs in this time period ${ }^{4}$. Overall, these mixing events provide the dominant source of some limiting nutrients $(\mathrm{P}, \mathrm{Si})$ to the surface waters and are important in maintaining the pelagic food web ${ }^{4-6}$.

Local records of air temperature from the Lake Tanganyika region show warming that is consistent with global patterns. Historical records show a rise of $0.5-0.7^{\circ} \mathrm{C}$ in average annual air temperatures (Fig. 1a), consistent with the global increase of $0.6 \pm 0.2^{\circ} \mathrm{C}$ (ref. 7). The trend towards higher temperatures began primarily in the late 1970s and coincides with the timing of regional precipitation and temperature changes documented in several climate studies ${ }^{8,9}$. On a regional scale, East Africa showed warm temperature anomalies from 1910 to 1930 , from 1940 to 1960 , and since the late 1970s (ref. 9).

The effects of climatic warming can be seen in water temperature data from Lake Tanganyika ${ }^{10-16}$. Upper water-column temperatures (150-m depth) show a significant warming trend of $0.1 \pm 0.01^{\circ} \mathrm{C}$ per decade since $1913\left(r^{2}=0.76, F=164, P<0.0001, n=53\right.$, linear regression; Fig. 2a). Deep-water temperatures (600-m depth), which do not show seasonal variation and are generally homothermal between $400 \mathrm{~m}$ and $1,000 \mathrm{~m}$, increased from $23.10^{\circ} \mathrm{C}$ in 1938 to $23.41^{\circ} \mathrm{C}$ in $2003\left(r^{2}=0.90, F=74.3, P<0.0001, n=10\right.$; refs $10-16$ and Fig. 2b). This increase of $0.31^{\circ} \mathrm{C}$ in deep-water temperature is comparable to that found in other African Great Lakes: Lake Victoria has warmed $0.3^{\circ} \mathrm{C}$ between the 1960 s and 1991 (ref. 17), the deep waters of Lake Malawi have warmed $0.29^{\circ} \mathrm{C}$ since 1953 (refs 18, 19), and Lake Albert has warmed $0.5^{\circ} \mathrm{C}$ since 1963 (ref. 20).

Along with increased temperatures, wind velocities in the Lake Tanganyika watershed have declined by $30 \%$ since the late 1970 s (Fig. 1b). Records show that monthly averages of wind velocity during the cool windy season in the north remained constant at $2.2 \pm 0.4 \mathrm{~m} \mathrm{~s}^{-1}$ until 1985, after which they decreased significantly to $1.6 \pm 0.3 \mathrm{~m} \mathrm{~s}^{-1}$ ( $z$-test, $\left.Z=7.54, P<0.0001, n=127\right)$. In the

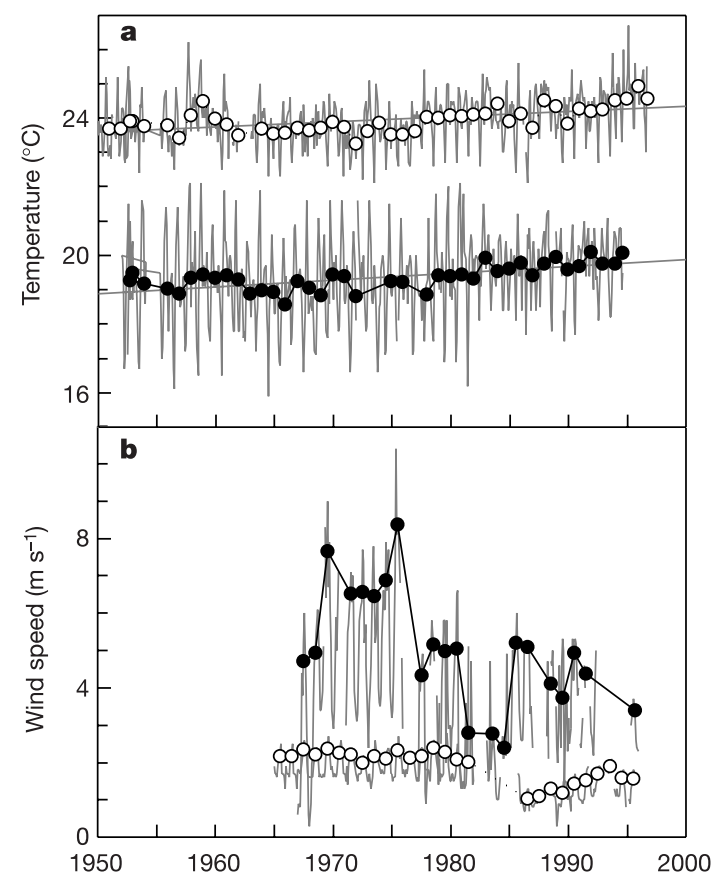

Figure 1 Historical meteorological records for the north (open circles) and south (filled circles) of Lake Tanganyika. a, Air temperatures. Monthly averages are shown in grey and are superimposed by annual means; regression (broken) lines are based on the full dataset. b. Wind speed. Monthly averages are shown in grey and are superimposed by windy season (May to September) means. 